\title{
Hubungan Kehamilan Lewat Waktu dan Preeklampsia Berat (PEB) dengan Kejadian Asfiksia Neonatorum
}

\author{
${ }^{1}$ P.Mandasari*, \\ ${ }^{1}$ Program Studi Diploma III Kebidanan, Akademi Kebidanan Rangga Husada Prabumulih \\ Email : dwipera86@yahoo.com
}

\section{Kata kunci :}

Kehamilan lewat waktu,

Preeklamsia berat,

Asfiksia neonatorum.

Keywords :

Pregnancy over time, Severe preeclampsia, Asphyxia neonatorum.

\section{Info Artikel:}

Tanggal dikirim:

23 Maret 2020

Tanggal direvisi:

16 Mei 2020

Tanggal diterima :

22 Juni 2020

\section{DOI Artikel:}

10.33862/citradelima. v4i1.98

Halaman: 36 - 40
Abstrak
Asfiksia neonatorum ialah keadaan dimana bayi tidak dapat segera bernafas secara spontan dan teratur (Prawirohardjo, 2010). Tujuan penelitian adalah untuk mengetahui hubungan kehamilan lewat waktu dan preeklampsia berat dengan kejadian asfiksia neonatorum di RSUD Kota Prabumulih. Metode penelitian bersifat analitik, dengan menggunakan pendekatan Cross Sectional. Populasi penelitian ini adalah seluruh ibu yang melahirkan diruang kebidanan RSUD Kota Prabumulih. Metode pengambilan sampel penelitian dengan metode random sampling yaitu 321 orang. Hasil penelitian berdasarkan dari analisa bivariat diketahui bahwa dari 26 responden yang mengalami kehamilan lewat waktu terdapat 19 responden $(5,9 \%)$ yang melahirkan bayi dengan asfiksia, sedangkan dari 295 responden yang tidak mengalami kehamilan lewat waktu terdapat 38 responden $(11,9 \%)$ yang melahirkan bayi dengan asfiksia, dari 55 responden yang mengalami preeklampsia berat terdapat 40 responden (12,5\%) yang melahirkan bayi dengan asfiksia, sedangkan dari 266 responden yang tidak mengalami preeklampsia berat terdapat 17 responden $(5,3 \%)$ yang melahirkan bayi dengan asfiksia. Kesimpulan ada hubungan yang bermakna antara kehamilan lewat waktu dengan kejadian asfiksia dengan nilai p-value $0,000 \leq \alpha 0,05$ dan ada hubungan yang bermakna antara preeklampsia berat dengan kejadian asfiksia dengan nilai $P$ value $0,000 \leq 0,05$.

\section{Relationship of Pregnancy Through Heavy Time and Preeklampsia (PEB) with the Event of Neonatorum Asfixia}

\begin{abstract}
Asphyxia neonatorum is a condition where the baby cannot breathe spontaneously and regularly (Prawirohardjo, 2010). The purpose of this study was to determine the relationship of pregnancy over time and severe preeclampsia with the incidence of asphyxia neonatorum in Prabumulih City Hospital. The research method is analytic, using the Cross Sectional approach. The study population was all mothers who gave birth in the midwifery room of Prabumulih City Hospital. The research sampling method with a random sampling method is 321 people. The results of the study are based on bivariate analysis it is known that of the 26 respondents who experienced a pregnancy beyond time there were 19 respondents $(5.9 \%)$ who gave birth to a baby with asphyxia, while of 295 respondents who did not experience a pregnancy beyond the time there were 38 respondents $(11.9 \%)$ who delivered babies with asphyxia, of the 55 respondents who experienced severe preeclampsia there were 40 respondents $(12.5 \%)$ who gave birth to babies with asphyxia, while of the 266 respondents who did not experience severe preeclampsia there were 17 respondents $(5.3 \%)$ who gave birth to a baby with asphyxia. Conclusions there is a significant relationship between pregnancy over time with the incidence of asphyxia with a $\mathrm{P}$ value of $0,000 \leq \alpha 0.05$ and there is a significant relationship between severe preeclampsia with the incidence of asphyxia with a $\mathrm{P}$ value of $0,000 \leq 0.05$.
\end{abstract}




\section{PENDAHULUAN}

Menurut World Health Organization (WHO), setiap tahunnya terdapat 120 juta bayi lahir di dunia, secara global empat juta bayi lahir mati dan empat juta lainnya meninggal dalam usia 30 hari (neonatal lanjut). Berdasarkan data World Health Organization (WHO), setiap tahunnya kira-kira 3,6 juta (3\%) dari 120 juta bayi mengalami asfiksia neonatorum di dunia, hampir 1 juta (27,78\%) bayi ini meninggal (Sukmawati, 2015). Di Indonesia angka kejadian asfiksia kurang lebih 40 per 1000 kelahiran hidup, secara keseluruhan 110.000 neonatus meninggal setiap tahun karena asfiksia (Rahmah, 2012).

Asfiksia neonatorum merupakan bayi baru lahir yang mengalami gagal bernafas secara spontan dan teratur segera setelah lahir, sehingga bayi tidak dapat memasukan oksigen dan tidak dapat mengeluarkan zat asam arang dari tubuhnya. Asfiksia dapat terjadi karena kurangnya kemampuan organ pernafasan bayi dalam mejalankan fungsinya, seperti pengembangan paru-paru (Karlina, 2014).

Faktor penyebab terjadinya asfiksia neonatorum adalah faktor dari ibu yaitu, Preeklampsia dan eklampsia, pendarahan abnormal (plasenta previa atau solusio plasenta), partus lama atau partus macet, demam selama persalinan Infeksi berat, kehamilan Lewat Waktu (sesudah 42 minggu kehamilan). Kemudian faktor tali pusat yaitu, lilitan tali pusat, tali pusat pendek, simpul tali pusat, prolapsus tali pusat. Faktor dari fetus (keadaan bayi) yaitu, bayi prematur (sebelum 37 minggu kehamilan), persalinan dengan tindakan, kelainan bawaan (kongenital), air ketuban bercampur mekonium (warna kehijauan) (Sukmawati, 2015).

Pencegahan asfiksia dapat dimulai dari masa kehamilan, persalinan dan beberapa saat setelah persalinan, diantara nya dengan cara melakukan pemeriksaan antenatal rutin minimal 4 kali kunjungan, melakukan rujukan ke fasilitas pelayanan kesehatan yang lebih lengkap pada kehamilan yang diduga berisiko bayinya lahir dengan asfiksia, memberikan terapi kortikosteroid antenatal untuk persalinan pada usia kehamilan kurang dari 37 minggu, melakukan pemantauan yang baik terhadap kesejahteraan janin dan deteksi dini tehadap tanda-tanda asfiksia selama persalinan dengan kardiotokografi, meningkatkan keterampilan tenaga obstetric dalam penanganan asfiksia dimasing-masing tingkat pelayanan kesehatan (Prawirohardjo, 2014).

Menurut penelitian Laeli Sukmawati (2015) tentang hubungan antara kehamilan lewat waktu (post term ) dengan kejadian asfiksia di RSUD Ambarawa dari 270 responden didapatkan nilai $p$-value $=0,004$ artinya ada hubungan bermakna antara kehamilan post term dengan terjadinya asfiksia.

Berdasarkan data dari rumah sakit umum daerah kota Prabumulih, pada tahun 2016 terdapat 143 bayi baru lahir dengan asfiksia neonatorum dari 1442 ibu bersalin, pada tahun 2017 terdapat 150 bayi baru lahir dengan asfiksia neonatorum dari 1385 ibu bersalin dan pada tahun 2018 terdapat 162 bayi baru lahir dengan asfiksia neonatorum dari 1425 ibu bersalin di Rumah Sakit Umum Daerah Kota Prabumulih.

\section{METODE}

Jenis penelitian ini menggunakan survey analitik dengan pendekatan Cross Sectional Study ialah suatu penelitian untuk mempelajari dinamika korelasi antara faktor-faktor resiko dengan efek dengan cara pendekatan observasi / pengumpulan data sekaligus pada suatu saat (Notoatmodjo, 2010).

Populasi penelitian ini adalah seluruh ibu yang melahirkan yang dirawat diruang kebidanan RSUD Kota Prabumulih dari tanggal 1 Januari sampai dengan 31 Desember 2018 yaitu sebanyak 1622 orang.

Sampel adalah sebagian atau wakil dari populasi yang akan diteliti (Notoatmodjo, 2010). Sampel dalam http://jurnalilmiah.stikescitradelima.ac.id/index.php/JI Vol.4,No.1, Juli 2020 
penelitian ini menggunakan teknik Random Sampling. maka sampel yang digunakan pada penelitian ini sebanyak 321 orang.

Data penelitian ini menggunakan data sekunder yang diperoleh dari data rekam medis di Rumah Sakit Umum Daerah Kota Prabumulih. analisis data yang digunakan adalah analisis univariat dan analisis bivariat. Analisis Univariat bertujuan untuk menjelaskan atau mendeskripsikan karakteristik setiap variabel penelitian.

Analisis Bivariat yang digunakan terhadap dua variabel yang diduga berhubungan atau berkolerasi. Analisis data dilakukan dengan menggunakan program Statistic Package Sosial Science (SPSS). Sehingga didapatkan bermakna jika nilai $p<0.05$ keputusan dari uji statistic Chi-Square.

\section{HASIL DAN PEMBAHASAN}

Hasil

Tabel 1. Hubungan antara kehamilan lewat waktu dengan kejadian asfiksia di RSUD Kota Prabumulih

\begin{tabular}{|c|c|c|c|c|c|c|c|}
\hline \multirow{3}{*}{$\begin{array}{c}\text { Kehami } \\
\text { lan } \\
\text { lewat } \\
\text { waktu }\end{array}$} & \multicolumn{4}{|c|}{ Kejadian Asfiksia } & \multirow{2}{*}{\multicolumn{2}{|c|}{ Jumlah }} & \multirow{3}{*}{$\begin{array}{l}P \text { - } \\
\text { Val } \\
\text { ue }\end{array}$} \\
\hline & \multicolumn{2}{|c|}{$\mathrm{Ya}$} & \multicolumn{2}{|c|}{ Tidak } & & & \\
\hline & $\mathrm{n}$ & $\%$ & $\mathrm{n}$ & $\%$ & $\mathrm{~N}$ & $\%$ & \\
\hline $\mathrm{Ya}$ & 19 & 5,9 & 7 & 2,2 & 26 & 8,1 & \\
\hline Tidak & 38 & 11,9 & 257 & 80 & 295 & 91,9 & 0 \\
\hline Jumlah & 57 & 17,8 & 264 & 82,2 & 321 & 100 & \\
\hline
\end{tabular}

Dari tabel diatas dapat dilihat bahwa dari 321 responden terdapat 26 responden yang mengalami kehamilan lewat waktu terdapat 19 responden $(5,9 \%)$ yang melahirkan bayi dengan asfiksia dan 7 responden (2,2\%) yang tidak didiagnosa asfiksia sedangkan dari 295 responden yang tidak mengalami kehamilan lewat waktu terdapat 38 responden $(11,9 \%)$ yang melahirkan bayi dengan asfiksia dan 257 responden (80\%) yang tidak didiagnosa asfiksia.

Hasil Uji statistic Chi-Square didapatkan p-value $=0,000$ artinya kehamilan lewat waktu dengan kejadian asfiksia ada hubungan yang bermakna, sehingga hipotesis yang menyatakan ada hubungan yang bermakna antara kehamilan lewat waktu dengan kejadian asfiksia terbukti secara statistik.

Tabel 2. Hubungan antara preeklampsia berat dengan kejadian asfiksia di RSUD Kota Prabumulih

\begin{tabular}{|c|c|c|c|c|c|c|c|}
\hline \multirow{3}{*}{$\begin{array}{c}\text { Preekla } \\
\text { msia } \\
\text { Berat }\end{array}$} & \multicolumn{4}{|c|}{ Kejadian Asfiksia } & \multirow{2}{*}{\multicolumn{2}{|c|}{ Jumlah }} & \multirow{3}{*}{$\begin{array}{l}P \text { - } \\
\text { Val } \\
\text { ue }\end{array}$} \\
\hline & \multicolumn{2}{|c|}{$\mathrm{Ya}$} & \multicolumn{2}{|c|}{ Tidak } & & & \\
\hline & $\mathrm{n}$ & $\%$ & $\mathrm{n}$ & $\%$ & $\mathrm{~N}$ & $\%$ & \\
\hline Ya & 40 & 12,5 & 15 & 4,6 & 55 & 17,1 & \\
\hline Tidak & 17 & 5,3 & 249 & 77,6 & 266 & 82,9 & 0,00 \\
\hline Jumlah & 57 & 17,8 & 264 & 82,2 & 321 & 100 & 0 \\
\hline
\end{tabular}

Dari tabel diatas dapat dilihat bahwa dari 321 responden terdapat 55 responden yang mengalami preeklampsia berat dimana 40 responden $(12,5 \%)$ yang melahirkan bayi dengan asfiksia dan 15 responden (4,6\%) tidak didiagnosa asfiksia sedangkan dari 266 responden yang tidak mengalami preeklampsia berat terdapat 17 responden $(5,3 \%)$ yang melahirkan bayi dengan asfiksia dan 249 responden $(77,6 \%)$ yang tidak didiagnosa asfiksia.

Hasil Uji statistic Chi-Square didapatkan p-value $=0,000$ artinya antara preeklampsia berat dengan kejadian asfiksia ada hubungan yang bermakna, sehingga hipotesis yang menyatakan ada hubungan yang bermakna antara preeklampsia berat dengan kejadian asfiksia terbukti secara statistik.

\section{Pembahasan}

Hubungan kehamilan lewat waktu dengan kejadian asfiksia di RSUD Kota Prabumulih.

Hasil analisis bivariat menunjukan bahwa dari 321 responden terdapat 26 responden yang mengalami kehamilan lewat waktu terdapat 19 responden $(5,9 \%)$ yang melahirkan bayi dengan asfiksia dan 7 responden (2,2\%) yang tidak didiagnosa asfiksia sedangkan dari 295 responden yang mengalami kehamilan lewat waktu terdapat 38 responden $(11,9 \%)$ yang melahirkan bayi

http://jurnalilmiah.stikescitradelima.ac.id/index.php/JI Vol.4,No.1, Juli 2020 
dengan asfiksia dan 257 responden (80\%) yang tidak didiagnosa asfiksia.

Hasil Uji statistic Chi-Square didapatkan $p$ value $=0,000$ artinya kehamilan lewat waktu dengan kejadian asfiksia ada hubungan yang bermakna, sehingga hipotesis yang menyatakan ada hubungan yang bermakna antara kehamilan lewat waktu dengan kejadian asfiksia terbukti secara statistik.

Hasil penelitian ini sejalan dengan hasil penelitian Laeli Sukmawati (2015) tentang hubungan antara kehamilan lewat waktu (post term ) dengan kejadian asfiksia di RSUD Ambarawa dari 270 responden didapatkan nilai $p$-value $=0,004$ artinya ada hubungan bermakna antara kehamilan post term dengan terjadinya asfiksia.

Pada kehamilan lewat waktu (post term) terjadi masalah dimana plasenta yang tidak sanggup memberikan nutrisi dan pertukaran $\mathrm{CO}_{2}$ sehingga janin mempunyai resiko asfiksia sampai kematian dalam rahim. Makin menurunnya sirkulasi darah menuju sirkulasi plasenta dapat mengakibatkan pertumbuhan janin makin lambat, terjadinya metabolisme janin, air ketuban makin kental, berkurangnya nutrisi $\mathrm{O}_{2} \mathrm{ke}$ janin yang menimbulkan asfiksia dan setiap saat dapat meninggal dalam rahim, saat persalinan janin lebih mudah mengalami asfiksia (Manuaba, 2010).

\section{Hubungan preeklampsia berat dengan kejadian asfiksia di RSUD Kota Prabumulih.}

Hasil analisis bivariat menunjukan bahwa dari 321 responden terdapat 55 responden yang mengalami preeklampsia berat dimana 40 responden $(12,5 \%)$ yang melahirkan bayi dengan asfiksia dan 15 responden (4,6\%) tidak didiagnosa asfiksia sedangkan dari 266 responden yang mengalami preeklampsia berat terdapat 17 responden $(5,3 \%)$ yang melahirkan bayi dengan asfiksia dan 249 responden $(77,6 \%)$ yang tidak didiagnosa asfiksia.

Hasil uji statistic Chi-Square didapatkan p-value
$=0,000$ artinya antara preeklampsia berat dengan kejadian asfiksia ada hubungan yang bermakna, sehingga hipotesis yang menyatakan ada hubungan yang bermakna antara preeklampsia berat dengan kejadian asfiksia terbukti secara statistik.

Hasil penelitian ini sejalan dengan hasil penelitian Suryaningsih (2012) tentang hubungan antara preeklampsia berat dengan kejadian asfiksia pada bayi baru lahir di Rumah Sakit Umum daerah Dr. H. Abdul Moeloek Bandar Lampung tahun 2011, dari 73 ibu yang mengalami preeklampsia berat, $51(69,9 \%)$ bayi yang dilahirkan mengalami asfiksia dan berdasarkan hasil uji statistik menggunakan analisis chi-square dengan didapatkan hasil X2hitung $(85,68)>$ X2tabel $(3,841)$, artinya ada hubungan bermakna antara preeklampsia berat dengan kejadian asfiksia pada bayi baru lahir.

Peningkatan pemindahan sel tropoblast akan menyebabkan kegagalan pengiriman darah melalui pembuluh arteri sehingga menyebabkan iskemia pada plasenta. Mengecilnya aliran darah menuju sirkulasi plasenter pada ibu hamil dengan preeklamsia menimbulkan gangguan pertukaran nutrisi, $\mathrm{CO} 2$ dan $\mathrm{O} 2$ yang menyebabkan asfiksia. Penyempitan arteriola yang mendadak menyebabkan asfiksia berat sampai kematian janin, bila spasme berlangsung lama dapat mengganggu pertumbuhan janin. Berkurangnya aliran darah pada uterus akut menyebabkan berkurangnya aliran oksigen ke plasenta dan ke janin, kondisi ini sering ditemukan pada gangguan kontraksi uterus, hipotensi mendadak pada ibu karena perdarahan, hipertensi pada preeklamsia (Suryaningsih, 2012).

\section{SIMPULAN}

Dari hasil penelitian yang dilakukan di Rumah Sakit Umum Kota Prabumulih tentang hubungan kehamilan lewat waktu dan preeklampsia berat dengan kejadian asfiksia, maka dapat disimpulkan, ada hubungan antara kehamilan lewat waktu dengan kejadian asfiksia di RSUD kota Prabumulih tahun 2018 dengan Chihttp://jurnalilmiah.stikescitradelima.ac.id/index.php/JI Vol.4,No.1, Juli 2020 
Square didapatkan $p$-value $=0,000$ lebih kecil dari $\leq($

0,05). Ada hubungan antara kehamilan lewat waktu dengan kejadian asfiksia di RSUD Kota Prabumulih tahun 2018 dengan Chi square didapatkan $p$ value $=$ 0,000 lebih kecil dari $\leq(0,05)$

\section{DAFTAR PUSTAKA}

Karlina. (2014). Pelayanan Kesehatan Maternal dan Neonatal. Edisi Pertama. Bandung. Media Aesculapius.

Manuaba, I, B, G. Bagus Gede. (2010). Ilmu Kebidanan, Penyakit Kandungan dan KB, Jakarta, ECG.

Notoatmodjo,S. (2010). Ilmu Kesehatan Masyarakat. Jakarta. Rineka Cipta.

Prawirohardjo, Sarwono. (2010). Pelayanan Kesehatan Maternal dan Neonatal. Edisi Pertama. Jakarta. YBP-SP.

Sukmawati,Laeli. (2015). Hubungan kehamilan lewat waktu dengan kejadian asfiksia di RSUD Ambarawa.

Suryaningsih. (2012). Hubungan preeclampsia berat dengan asfiksia pada bayi baru lahir di RSUD Dr.H.Abdul Moeloek Bandar lampung. 